\title{
Trypanosoma cruzi-cardiomyocytes: New Contributions Regarding a Better Understanding of this Interaction
}

\author{
Maria de Nazareth Leal de Meirelles/ ${ }^{+}$, Mirian Claudia S Pereira, \\ Robert H Singer*, Maria de Nazaré C Soeiro, Luciana R Garzoni, \\ Dayse T Silva, Helene S Barbosa, Tania C Araujo-Jorge, Masako O Masuda**, \\ Marcia AM Capella***, Anibal Gil Lopes***, Alane B Vermelho****
}

Laboratório de Ultra-estrutura Celular, Instituto Oswaldo Cruz, Av. Brasil 4365, 21045-900, Rio de Janeiro, RJ, Brasil *Albert Einstein College of Medicine, Bronx, New York, 10461, USA **Laboratório de Eletrofisiologia Cardíaca ***Laboratório de Fisiologia Renal, IBCCF, CCS, UFRJ, Rio de Janeiro, RJ, Brasil ****Instituto de

Microbiologia, UFRJ, Ilha do Fundão, Rio de Janeiro, RJ, Brasil

The present paper summarizes new approaches regarding the progress done to the understanding of the interaction of Trypanosoma cruzi-cardiomyocytes. Mannose receptors localized at the surface of heart muscle cell are involved in binding and uptake of the parasite. One of the most striking events in the parasite-heart muscle cells interaction is the disruption of the actin cytoskeleton. We have investigated the regulation of the actin mRNA during the cytopathology induced in myocardial cells by the parasite. T. cruzi invasion increases calcium resting levels in cardiomyocytes. We have previously shown that $\mathrm{Ca}^{2+}$ ATPase of the sarcoplasmic reticulum (SERCA) is involved in the invasion of $\mathrm{T}$. cruzi in cardiomyocytes. Treating the cells with thapsigargin, a drug that binds to all SERCA ATPases and causes depletion of intracellular calcium stores, we found a $75 \%$ inhibition in the T. cruzi-cardiomyocytes invasion.

Key words: Trypanosoma cruzi - cardiomyocytes - calcium - SERCA ATPases - mannose receptor mRNA regulation

Cardiomyocytes $(\mathrm{CM})$ are the main targets for Trypanosoma cruzi infection in Chagas disease. It is generally accepted that calcium ions play an important role throughout the contraction-relaxation cycle of muscle cells. Furthermore, the existing literature shows the importance of calcium ions during the interaction of $T$. cruzi with different cell types (Tardieux et al. 1994, Moreno et al. 1994, Burleigh \& Andrews 1995, Yoshida 1997, Garzoni et al. 1998, Caler et al. 1998). Sarcoplasmic reticulum (SR) performs calcium sequestration by a calcium stimulated ATPase (SERCA). Thapsigargin is a tumor promoting sesquiterpene lactone that binds itself to all SERCA ATPases leading to irreversible inhibition of their activity. When this drug was used during the interaction of T. cruzi, heart muscle cells showed a marked inhibition of the infection (Silva \& Meirelles 1998). When invasive forms of $T$. cruzi-amastigote and trypomastigote enter in contact with the surface of

\footnotetext{
${ }^{+}$Correponding author. Fax: $+55-21-260.4434$. E-mail: meirelle@ ioc.fiocruz.br

Received 9 June 1999

Accepted 9 August 1999
}

host cells they induce a special endocytic process which leds to the formation of a vacuole known as parasitophorous vacuole (PV). It has been described that during the formation of the PV some host cell plasma membrane components will be part of the membrane of the PV, but other components will not be found in the membrane which lines the PV. The involvement of glycoconjugates in this invasion have shown that a number of carbohydrates - such as galactose, $\mathrm{N}$-acetyl galactosamine, $\mathrm{N}$ acetyl glucosamine, mannose and sialic acid - components of glycoproteins and glycolipids present on the surface of both parasite and/or host cell may participate in the interaction process (Andrews \& Coli 1981, Crane \& Dvorak 1982, Vilalta \& Kierzenbaum 1983, 1985, Zingales \& Coli 1985, Meirelles et al. 1986, Piras et al. 1987, Ouassi 1988, Vermelho et al. 1992, Barbosa \& Meirelles 1992, Schenkman \& Eichinger 1993, Vermelho \& Meirelles 1994, Soeiro et al. 1995). Mannosyl residues and their counter-receptors play an important role during the interaction of $T$. cruzi and host cells. They have been implicated as ligands during host cell invasion and have been localized at the PV membrane of macrophages and cardiomyocytes (Barbosa \& Meirelles 1992, Araujo-Jorge et al. 1993). We analysed the mannose receptor (MR) in primary cultures of heart muscle cells and during 
its interaction with T. cruzi (Soeiro et al. 1999). The actin cytoskeleton plays an important role in many cellular processes including the parasite invasion in mammalian cells. We have described alterations in the cytoskeleton organization in the cardiomyocytes $T$. cruzi-infected (Pereira et al. 1993). We have investigate the regulation of the actin mRNA during the cytopathology induced in myocardial cells by the parasite.

\section{MANNOSE RECEPTORS AT THE SURFACE OF CARDIOMYOCYTES}

Carbohydrate-protein interactions play an important role in a large variety of biological and pathological events. The mannose receptor (MR) is able to recognize a wide range of Gram-negative and Gram-positive bacteria, mycobacteria, yeast and parasites. Previously, it was thought that its expression was restricted to tissue macrophage but now it is known that it is expressed in other cells as subsets of endothelial cells, smooth muscle cells, retinal pigment epithelium, kidney mesangial cells, myeloid cells and Kaposi sarcoma cells (reviewed in Stahl \& Ezekovitz 1998). We analysed the mannose receptors in primary cultures of cardiomyocytes (CM) from mouse embryos for studies of parasite-cell interaction (Meirelles et al. 1986, Soeiro et al. 1997). Horseradish peroxidase (HRP) was used as ligand to localize the MR. HRP is a glycoprotein devoid of phosphorylated carbohydrates and rich in mannose and $\mathrm{N}$-acetylglucosamine groups. The role of mannosyl residues and MR during this interaction was tested by carbohydrate addition during CM-parasite uptake. Infection rates were analysed by the addition of 10 or $50 \mathrm{mM}$ of D-mannose during the infection for $24 \mathrm{hr}$ at $37^{\circ} \mathrm{C}$ in Eagle's medium without serum. After host cell-parasite interaction, cultures were fixed in Bouin, stained with Giemsa and the percentage of infected CM was calculated. Ultrastructural studies for MR detection were also performed using HRP coupled to colloidal gold particles (HRP-Au) as probe. Non-infected CM were first incubated incubated with HRP-Au for $30 \mathrm{~min}$ at $4^{\circ} \mathrm{C}$ and then the temperature was elevated to $37^{\circ} \mathrm{C}$ and followed for 1 and $4 \mathrm{hr}$. Some cultures were incubated with HRP-Au for 30 min at $4^{\circ} \mathrm{C}$, washed and infected for $24 \mathrm{hr}$ at $37^{\circ} \mathrm{C}$ with metacyclic trypomastigote forms.

The addition of D-mannose to the interaction medium impaired the parasite uptake by the CM, being the concentration of $10 \mathrm{mM}$ proved to be the most effective. The ultrastructural studies showed, in non-infected CM, the tracer over the sarcolemma, near or inside uncoated vesicles, in caveolae and also in endocytic vesicles. In infected $\mathrm{CM}$, gold particles were seen at the site of parasite-sarcolemma association and also inside the parasitophorous vacuole containing parasite. These results indicated that the mannose receptors localized at the surface of CM are involved in the binding and uptake of T. cruzi (Soeiro et al. 1999).

\section{T. CRUZI INFECTION AFFECTS mRNA REGULATION IN CARDIOMYOCYTES}

Our in vitro system of cardiac cell cultures allowed to study biological and molecular events in the T. cruzi-CM. When this parasite invades and develops its intracellular cycle within heart cells, many alterations occur resulting in cytoskeleton disruption and myofibrillar breakdown in regions where the intracellular parasites are located, followed by the formation of actin polygons (Pereira et al. 1993). Then, we hypothesized that the regulation of actin mRNA would be, in the same way, affected. Our aim was to understand the molecular basis for the regulation of cytoskeleton proteins mRNA during CM differentiation and also after their infection with $T$. cruzi. Total cellular RNA was isolated from normal and T. cruzi infected CM using Tri-Reagent (Molecular Research Center, Inc.) Oligonucleotides probes were made to 3'untranslated region of both actin mRNAs. Agarose gel electrophoresis and Northern Blotting analysis were carried out using standard procedures. GAPDH mRNA probe was used as internal standard.

The analysis of isoactin mRNAs expression during cardiomyogenesis in vitro showed a decrease in both cytoplasmic isoforms ( $\beta$ and $\gamma$ ) mRNAs concomitant with an increase in $\alpha$-cardiac actin mRNA level. $T$. cruzi infected cells revealed a reduction of $50 \%$ in the $\alpha$-cardiac actin mRNA expression with $72 \mathrm{hr}$ of infection. In contrast, $\beta$ actin mRNA increased $47 \%$ after $48 \mathrm{hr}$ of infection. In situ hybridization demonstrated that $\alpha$-cardiac, $\gamma$ and $\beta$ cytoplasmatic actin were located in different compartments during cell myogenesis which corroborates with the concept that most mRNA are addressed to the functional protein compartment. Non-muscle cells displayed $\beta$-actin mRNA signal at the cell perifery, while $\alpha$-cardiac actin mRNA had a perinuclear distribution in myocytes. After $T$. cruzi infection, $\beta$-actin mRNA was translocated from the periphery to the perinuclear region in highly infected cells. The changes observed over the distinct pattern of isoactin mRNAs expression during cardiac myogenesis were induced by $T$. cruzi infection. These results provide evidence that $T$. cruzi affects actin mRNA regulation.

THE ROLE OF CALCIUM IONS DURING THE INTERACTION OF T. CRUZI-CARDIOMYOCYTES

T. cruzi trypomastigote forms invade a variety of mammaliam cells triggering transient increases 
in the $\left[\mathrm{Ca}^{2+}\right]_{\mathrm{i}}$ an effect not observed with the non infective epimastigote stage (Tardieux et al. 1994, Moreno et al. 1994, Burleigh \& Andrews 1995, Dorta et al. 1995, Caler et al. 1998). According to Tardieux et al. (1994), the $\mathrm{Ca}^{2+}$ transients induced in host cells would promote the invasion by recruiting the lysosomes at the site of parasite entry. The $\mathrm{Ca}^{2+}$ signalling activity from $T$. cruzi is soluble and linked to the activity of a parasite serine hydrolase, the oligopeptidase B (Burleigh \& Andrews 1995, Caler et al. 1998). Also, the finding of elevated $\left[\mathrm{Ca}^{2+}\right]_{i}$ in trypomastigote forms during the process of cell invasion (Dorta et al. 1995, Moreno et al. 1994) suggests that the parasite posssesses the ability to control its own $\mathrm{Ca}^{2+}$ levels, possibly through regulation of influx or mobilization from intracellular stores. Treatments which decrease or elevate cytoplasmic $\mathrm{Ca}^{2+}$ (Yakubu et al. 1994) showed that a decrease or increase in $T$. cruzi $\left[\mathrm{Ca}^{2+}\right]_{\mathrm{i}}$ modifies infectivity downward or upward, respectively.

To study the role of calcium ions in the invasion of cultured cardiac myocytes we used fura-2, a dual ratiometric fluorescent $\mathrm{Ca}^{2+}$ indicator. For fura-2, significants shifts are observed in the excitation spectra, but not in the emission spectra. $\mathrm{Ca}^{2+}$ free and $\mathrm{Ca}^{2+}$-bound forms of ratiometric indicators are characterized by spectral peaks at different wavelenghts, and intensity measurements can be made at two different wavelenghs and a ratio can be obtained. Cardiomyocytes were incubated with fura-2-AM, $4 \mathrm{mg} / \mathrm{ml}$ in Eagle medium for 20 min, then rinsed and maintained in Eagle's medium. They were analyzed with an inverted Carl Zeiss microscope - Attofluor digital fluorescence ratio imaging system. Profiles of fluorescence intensity were obtained before and after the interaction with T. cruzi. Fura- 2 monitored the intracellular calcium in normal cardiomyocytes for $1 \mathrm{hr}$; for interaction studies after the observation of normal cells, trypomastigotes forms of $T$. cruzi were added to the cultures. Our results showed a significant increase in intracellular calcium levels during the invasion process. We observed transients $\mathrm{Ca}^{2}+$ increases when the parasite only touched the cell, but did not adhere. When the parasite was seen adhered to the cell, a constant increase in $\mathrm{Ca}^{2}+$ was registered (Garzoni et al. 1998).

We have previously shown that $\mathrm{Ca}^{2}+$ ATPase of the SERCA was involved in the process of invasion of cardiomyocytes by $T$. cruzi (Silva \& Meirelles 1998). Treating cardiomyocytes with 2, 4 and $6 \mu \mathrm{M}$ of thapsigargin, during 3 and $6 \mathrm{hr}$, a drug that depletes intracellular calcium stores, we found a statistically significant inhibition $-75 \%$ in the T.cruzi-cardiomyocytes invasion. Further studies are being done to investigate how the $\mathrm{CM}$ excitation-contraction is affected during $T$. cruzi infection.

\section{REFERENCES}

Andrews NW, Colli W 1981. Interiorization of T. cruzi in cultured mamalian cells inhibition by $\mathrm{N}$-acetylglucosamine, p. 81, res. 104, XIII Anual Meeting on Basic Reasearch on Chagas Disease, Caxambu, Brasil.

Araujo-Jorge TC, Barbosa HS, Meirelles MNL 1993. Trypanosoma cruzi recognition by macrophages and muscle cells: perspectives after 15-year study. Mem Inst Oswaldo Cruz, 87: 43-56.

Barbosa HS, Meirelles MNL 1992. Ultrasructural detection in vitro of WGA, RCA and Con-A binding sites involved in the invasion of heart muscle cells by Trypanosoma cruzi. Parasitol Res 70: 404-409.

Burleigh, B and Andrews, NW 1995. A 120 kDa alkaline peptidase from Trypanosoma cruzi is involved in the generation of a novel Ca2+-signaling factor for mammalian cells. J Cell Biol 138: 999-1008.

Caler EV, Avalos SV, Haynes PA, Andrews NW, Burleigh BA 1998. Oligopeptidase B-dependent signaling mediates host cell invasion by Trypanosoma cruzi. EMBO J 17: 4975-4986.

Crane MJ, Dvorak JA 1982. Influence of monosacharides on the infection of vertebrate cells by Trypanosoma cruzi and Toxoplasma gondii. Mol Biochem Parasitol 5: 333-341.

Dorta ML, Ferreira AT, Oshiro MEM, Yoshida N 1995. Ca $2+$ signal induced by Trypanosoma cruzi metacyclic trypomastigote surface molecules implicated in mammalian cell invasion. Mol Biochem Parasitol 73: 285-289.

Garzoni L, Masuda MO, Capella MAN, Lopes, AG, Meirelles, MNL 1998. Trypanosoma cruzi invasion in cardiomyocytes increases the calcium resting level. Mem Inst Oswaldo Cruz 93 (Suppl. II): 86.

Meirelles MNL, Araujo-Jorge TC, De Souza W, Barbosa HS 1986. Interaction of Trypanosoma cruzi with heart muscle cells: ultrastructural and cytochemical analysis of endocytic vacuole formation and effect upon myogenesis in vitro. Eur J Cell Biol 41: 198206.

Moreno SNJ, Silva J, Vercesi AE, Do Campo, R 1994. Cytosolic free calcium elevation in Trypanosoma cruzi is required for cell invasion. J Exp Med 180: 1535-1540.

Ouassi MA 1988. Role of the RGD sequence in parasitic adhesion to host cell. Parasitol Today 4: 169173.

Pereira MC, Singer RH, Meirelles MNL 1997. Regulation and Localization of $\beta$ and $\alpha$-cardiac actin mRNAs in Trypanosoma cruzi infected heart muscle cells in vitro. Mem Inst Oswaldo Cruz, 92 (Suppl. I): 69.

Pereira MCS, Costa M, Chagas Filho C, Meirelles, MNL 1993. Myofibrillar breakdown and cytoskeletal alterations in heart muscle cells during invasion by Trypanosoma cruzi: immunological and ultrasructural study. J Submicrosc Cytol Pathol 25: 555-569. 
Piras MM, Henriquez O, Piras R 1987. The effect of fetuin and other sialoglycoprotein on the "in vitro" penetration of Trypanosoma cruzi trypomastigotes into fibroblastic cells. Mol Biochem Parasitol 122: 135-143.

Schenkman S, Eichinger D 1993. Trypanosoma cruzi transialidase and cell invasion. Parasitol Today 99: 218-222.

Silva DT, Meirelles MNL 1998. Expression of the endoplasmic reticulum enzymes in the Trypanosoma cruzi infected and non infected cardiomyocytes. Mem Inst Oswaldo Cruz 93 (Suppl. II): p. 116.

Soeiro MNC, Paiva MM, Barbosa HS, Meirelles MNL, Araujo-Jorge TC 1999. A cardiomyocytes mannose receptor system is involved in Trypanosoma cruzi invasion and is down-modulated after infection. Cell Structure and Function 24: 139-149.

Soeiro MNC, Barbosa HS, Meirelles, MNL, Paiva MM, Waghabi M G, Guimarães EV, Araujo-Jorge TC 1997. Mannose receptors localized at the surface of heart muscle cells are involved in the binding and uptake of Trypanosoma cruzi. Mem Inst Oswaldo Cruz 92 (Suppl. I): 76.

Soeiro MNC, Silva-Filho, Meirelles MNL 1995. Alterations in the surface charge of heart muscle cells during interaction with Trypanosoma cruzi. Cell Biophysics 26: 21-44.

Stahl PD, Ezekowitz RA 1998. The mannose receptor is a pattern recognition receptor involved in host defense. Curr Opin Immunol 10: 50-55.

Tardieux, I, Nathanson MH, Andrews NW 1994. Role on host cell invasion of Trypanosoma cruzi-induced cytoosloc free $\mathrm{Ca}^{2+}$ transients. J Exp Med 179: 1017 1022.

Vermelho AB, Meirelles, MNL 1994. Sialoglyconjugates in Trypanosoma cruzi-hosta cell interaction: possible biological model - a Review. Mem Inst Oswaldo Cruz 89: 69-79.

Vermelho AB, Barreto-Bergter E, Pereira, MC, Meirelles MNL 1992. Glycolipids and protein profile of normal and Trypanosoma cruzi infected heart muscle cells. Acta Trop 52: 17-25.

Vilalta F, Kierszenbaum F 1983. Role of cell surface mannose residues in host cell invasion by Trypanosoma cruzi. Biochem Biophys Acta 736: 39-44.

Vilalta F, Kierszenbaum F 1985. Role of Nacetylglucosamine residues on host cells infection by Trypanosoma cruzi. Biochem Biophys Acta 834: 216-222.

Yakubu MA, Majumder, S, Kierszembaum F 1994. Changes in Trypanosoma cruzi Infectivity by treatments that affect calcium ions levels. Mol Biochem Parasitol 66: 119-125.

Yoshida N, Dorta ML, Ferreira, AL, Oshiro MEM, Mortara, RA, Acosta-Serrano A, Favoreto Jr S 1997. Removal od sialic acid from mucin-like surface molecules of Trypanosoma cruzi metacyclic trypomastigotes enhances parsite-host cell interaction. Mol Biochem Parasitol 84: 57-67.

Zingales B, Colli, W 1985. Trypanosoma cruzi: Interaction with host cells. Curr Trop Microbiol Immunol 117: 129-147. 